DOI: 10.22616/REEP.2020.006

\title{
Music Education Innovations as a Condition for Development of Non-formal Education: Learning in a Group
}

\author{
Giedrė Gabnytė $\mathrm{PhD}$ \\ Lithuanian Academy of Music and Theatre, Lithuania \\ ggabnyte@yahoo.com
}

\begin{abstract}
The article presents the expression of music school teachers' attitude towards education innovations specifically focusing on one of them, i.e. on learning to play an instrument in a group. The author of the article attributes this kind of music education to innovations because individual learning to play an instrument is most common in teaching practice. Today the need of innovation in music education is proved by changing educational goals: education should create the environment, which would imitate real life situations, whereas learning should provide skills that are necessary in everyday life. Such essential skills mean the ability to communicate and collaborate. The aim of the research presented in this article is to identify the attitude towards music education innovations expressed by teachers from music schools, as one of conditions for development of non-formal children education, paying specific attention to peculiarities of learning an instrument in a group. In the first stage of the research, the questionnaire survey aimed to find out the attitude of music school teachers towards the innovation of music education as one of the conditions for the development of non-formal children's education. It was found that most teachers of music schools in Lithuania do not approve of instrument learning in a group, claiming that learning to play an instrument is only possible through individual teacher - student work. The second stage of the research, using focus interviews, aimed to reveal the peculiarities of learning the instrument in a group, using the views of the teachers applying this innovation in their work. According to the teachers, learning in a group focuses on the process rather than the result: learning in a group students not only play but also listen to music, they get to know music theory, communicate and collaborate. Making music in a group differs from the individual learning in more difficult lesson management, a variety of activities and the need for different teacher's competencies. The research revealed that the ability to apply the approach of individual learning in parallel with group learning in education is likely give more diversity in music learning, making it more engaging and inclusive.
\end{abstract}

Keywords: learning an instrument in a group, music school, music education innovations.

\section{Introduction}

The main goal of non-formal children education is to satisfy learners' cognitive, learning and selfexpression needs and to enable them to become proactive members of their society. Therefore, it is obvious that with increasing requirements for study subjects in formal education, non-formal education provides an equal counterpoint, which facilitates school learners' becoming a self-creating personality (Perulli, 2009; Romi, Schmida, 2009; Rogers, 2005; Thoidis, Pnevmatikos, 2014; Kaufmann, 2015). Non-formal children education in Lithuania has undergone various stages of development, shifts in models, transformations of names and today is regulated by a number of documents (Lietuvos Respublikos švietimo..., 2011; Valstybinès švietimo..., 2015; Vaikų ir jaunimo..., 2010; Neformaliojo vaikų švietimo..., 2012) that underline the significance of personal, educational, social and professional competences acquired in non-formal education, emphasise non-formal education as an opportunity to obtain tolerance skills, abilities to cope with problems, to gain an in-depth understanding of experience and traditions of own nation as well as to adopt them. The focus of this article is on music education in Lithuanian music schools, which is assigned to the structure of non-formal education and supplements formal education. Under considerable changes in the country's political and socio-cultural conditions, the question arises: to what extent does the "product" of 1940s - present music school and curriculum implemented in it - really comply with the new goals of education and training shaped by transformations in paradigms? According to the researchers focusing on education in music schools, education in the afore-said schools has not changed for many years: it is absolutely departed from the process of creation and the objectives of learner's esthetical development (Antilla, Lehtonen, 2007; Gabnyte, 2011; Kriščiūnaitè, Strakšienè, 2016; Laes, Schmidt, 2016; Björk, 2016; Gabnytė, 2019). A considerable drop- 
off rate among learners has become a common phenomenon in the process of education, which also shows that education is unattractive and does not reflect the needs of a present-day learner.

Nowadays learning an instrument in music schools is based on the tradition of individual teaching (Luff, Lebler, 2013), in terms of both education organisation (teaching is individual) and objectives of education (development of individuality). However, the current era has been gradually imposing new conditions on daily pedagogical activities. Educational recommendations emphasise the necessity for education to create the environment, which imitates real life situations, whereas learning should provide skills that are necessary in everyday life. Abilities to communicate, to collaborate and work in a team have been prioritised these days. According to L. Šiaučiukènienè (Šiaučiukėnienè, Stankevičienè, Čiužas, 2011), working in a group learners acquire better social skills, live through more intensive feelings of self-respect and responsibility, develop empathy, which allows them to better learn not only the self but also another person. It is not excluded that all these skills can be obtained through playing music. According to D.W. Luce (2001) and S. Hallam (2010), learning music in a group contributes to development of teamwork, communication and collaboration skills as well as those of pursuing a common goal. Learning to play an instrument in a group, a school child acquires a wide range of abilities and competences, which are not always developed during individual lessons: in a group a child learns to critically evaluate a peer playing music together, encounters a higher probability of experiencing joy of performing music. Moreover, music itself and its performing are perceived not only as a study subject but rather as part of social context (Swanwick, Swanwick, 1994; Daniel, 2004). According to D.A. Berezhnoi, learning to play an instrument in a group can be considered an innovation so far and further research and practice will show if such learning "takes roots" and becomes traditional (Berezhnoi, 2011). Some authors emphasise the significance of harmonising individual teaching and learning in a group: during individual classes a student is able to improve playing skills, whereas learning in a group enhances interpretation skills (Berezhnoi, 2011). It is interesting that most frequently researchers discuss if it is possible to learn playing the piano, i.e., the instrument, which is undoubtedly considered an exclusively solo instrument by its "nature", in a group (Bastien, 1999; Fairchild, 1996; Rowe, 1999).

The aim of the research presented in this article is to identify the attitude towards music education innovations expressed by teachers from music schools, as one of conditions for development of nonformal children education, paying specific attention to peculiarities of learning an instrument in a group.

\section{Methodology}

Seeking to identify the attitude of music school teachers in Lithuania towards music education innovations, the empiric research was conducted in two stages. The questionnaire survey was carried out during the first stage, which targeted at teachers of piano, string, folk music, guitar, brass-wind and percussion instruments from Vilnius and other Lithuanian towns and settlements. The sample of the questionnaire survey consisted of 367 respondents: $74.4 \%$ women and $25.6 \%$ men. There were $30.2 \%$ of the respondents with a working experience of 21-30 years, $41.8 \%$ of the respondents were holders of senior teacher's qualification, $34.3 \%$ of teachers methodologists, $18.5 \%$ of teachers and $5.4 \%$ of teachers experts. The piano teachers made up the biggest proportion of the respondents, whereas the number of bassoon teachers was the lowest. The second stage of the research was based on the focus group interview with teachers. The interviewees were selected following the principle of homogeneous sampling (the sampling includes similar or one-type cases from the same social layer, sharing common interests, experience, sociodemographic characteristics (Patton, 1990) and they included music teachers (1 piano teacher, 1 percussion teacher, 2 violin teachers and 2 guitar teachers) from 6 music schools in Vilnius, who apply one of music education innovations, i.e. learning an instrument in a group, in their teaching practice. The main research question was: what are the peculiarities of learning an instrument in a group, analyzing it by the aspects of lesson organization, the variety of activities, effect on learners' abilities, advantages and disadvantages. The research data were collected applying the methods of scholarly literature analysis, questionnaire survey and interview. A questionnaire was designed to identify the attitude of teachers from music schools towards learning an instrument in a group, which was based on Likert scaling methodology. The reliability of the diagnostic scales was measured calculating the value of Cronbach $\alpha$ coefficient (acceptable coefficient variation range $0.5 \leq \alpha<1$, values approaching the unit indicate high internal consistency of the test). Sorting the data variables were excluded if their significant loadings were less than $0,3(\mathrm{~L}<0.3)$. (The results of Cronbach $\alpha$ coefficient was: Differentiated education: Cronbach $\alpha-0.72$, L- 0.65/0.81 Need for experimentation: 
Cronbach $\alpha-0,7, \mathrm{~L}-0,69 / 0,88$ ). The data were processed applying statistical data analysis (SPSS 16.0 for Windows). Chi-square test was used to evaluate the statistical significance of correlations of the respondents' demographic data, professional factors and teacher's attitudes. A semi-structured interview questionnaire was designed to conduct the research on peculiarities of group learning. The data acquired during the focus group interviews were processed applying strategies of contextualisation and categorisation assigned to qualitative data analysis methods (Maxwell, 1996).

The constructivist qualitative research approach, i.e. construction of categories on the basis of obtained research data, was used, when the elements of the received data were compared with each other and the titles generalising the data content were assigned to the categories (Charmaz, 2006).

\section{Results and discussion}

To identify the attitude of music school teachers towards music education innovations, seven diagnostic scales were used. They targeted at clarifying opinions of teachers about differentiated education, change in assessment system, need for experimentation in education, possibilities of learning several specialities (instruments) in parallel, adult music education, special education and learning an instrument in a group. As it can be seen from the data in Table 1, the biggest number of teachers do not approve of learning an instrument in a group.

Table 1

The teachers' attitude towards music education innovations. Percentage frequencies $(\mathrm{N}=367)$

\begin{tabular}{|l|c|c|c|r|r|r|}
\hline \multicolumn{2}{|c|}{ Innovations } & \multicolumn{2}{c|}{ Disagree } & \multicolumn{2}{c|}{ Partially agree } & \multicolumn{2}{c|}{ Agree } \\
\cline { 2 - 7 } & $\mathbf{N}$ & $\mathbf{\%}$ & $\mathbf{N}$ & \multicolumn{1}{c|}{} & \multicolumn{1}{c|}{$\mathbf{N}$} & \multicolumn{1}{c|}{} \\
\hline 1. Differentiated education & 28 & 7.6 & 129 & 35.1 & 210 & 57.2 \\
\hline 2. Change in assessment system & 188 & 51.2 & 143 & 39 & 36 & 9.8 \\
\hline 3. Need for experimentation & 59 & 16.1 & 166 & 45.2 & 142 & 38.7 \\
\hline 4. Learning an instrument in a group & 191 & 52 & 136 & 37.1 & 40 & 10.9 \\
\hline 5. Adult music education & 16 & 4.4 & 78 & 21.3 & 273 & 74.4 \\
\hline 6. Special education & 17 & 4.6 & 83 & 22.6 & 267 & 72.8 \\
\hline 7.Possibility of learning several specialities at time & 60 & 16.3 & 136 & 37.1 & 171 & 46.6 \\
\hline
\end{tabular}

The significant factors that influence the expression of such an attitude of teachers were also distinguished. The results of Chi-square test revealed that a disapproval of applying learning an instrument in a group is possibly inspired by a negative attitude towards differentiated education and experimentation. It is likely that the stronger the disapproval of these innovative innovations, the stronger reluctance to include learning an instrument in a group into curriculum is identified (Table 2).

Table 2

The causal relationships of negative attitude towards learning in a group and factors influencing this attitude. The results of Chi-square tests $(\mathrm{N}=367)$

\begin{tabular}{lccc}
\hline \multicolumn{1}{c}{ Factors that influence the attitude } & Value & df & Sig (p) \\
\hline Differentiated education & 27.984 & 4 & 0.000 \\
Need for experimentation & 25.951 & 4 & 0.000 \\
\hline
\end{tabular}

NB. Value - chi-squared test, df - degrees of freedom, $\operatorname{Sig}(\mathbf{p})$ - statistical significance

The expression of such teachers' attitude is also influenced of some personal and professional factors (Table 3). A strong and statistically significant relationship was established between the aforesaid attitude and the subject taught: piano teachers seemed to be the most reluctant to introduce this innovation $(p=0.017)$. In fact, to teach the piano in a group is, probably, the most challenge or even hardly possible (according to sceptics) task. However, the supporters of learning an instrument in a group state that the goal of such learning exceeds that of improvement of playing skills only. As it can be seen from experience in music education accumulated in foreign countries, while playing in a group learners are provided with conditions not only to acquire certain playing skills but also to experience playing in an ensemble and to learn communication. The results of questionnaire surveys revealed that pedagogical qualification teachers had influence on formation of such an opinion among them. The results revealed that teachers-experts had the most contradicting opinion regarding this innovation, hence, elder teachers 
were most reluctant to learning an instrument in a group. It is logical to assume that older generation teachers are more loyal to education traditions, they tend to be guided by their pedagogical experience, they find it difficult to adapt to possible education challenges and practically implement innovative teaching. A statistically significant relationship was identified between the negative attitude towards learning in a group and the place of living: the teachers from Lithuanian cities were least willing to apply learning in a group $(p=0.002)$. Such a result proves that learners' high artistic achievements that enable them to participate in prestigious country events, such as concerts, festivals and competitions, are most important to teachers from cities. Distinguished students and a high number of winners in competitions create the conditions for teachers to seek higher degree qualifications and faster professional recognition.

Table 3

The influence of personal and professional factors on the attitude towards learning an instrument in a group. The results of Chi-square tests $(\mathrm{N}=367)$

\begin{tabular}{lccc}
\hline \multicolumn{1}{c}{ Factors that influence the attitude } & Value & df & Sig (p) \\
\hline Study subject taught & 18.546 & 8 & 0.017 \\
Place of residence & 28.147 & 10 & 0.002 \\
Pedagogical qualification & 18.088 & 6 & 0.006 \\
\hline
\end{tabular}

The negative attitude of music teachers towards learning an instrument in a group encouraged a more detailed analysis of peculiarities typical of this innovation more. A focus group interview with teachers, who apply this way of teaching in their teaching practice, was conducted. The teachers were asked about specific features of a group lesson aimed to learn an instrument. What is characteristic of managing such lessons? What activities are possible during such lessons? What valuable things can be learnt during group lessons? The interview disclosed that teachers encounter serious challenges delivering group lessons. One of them includes in indetermination of criteria for selecting learners to the group and an optimal number of learners in it. The respondents stated that the groups are most frequently formed on the basis of learners' age, sometimes according to the year of studies or level of learning. In some cases, groups have to be reformed due to different achievements of learners, what causes stress to teachers as well as learners. According to the teachers, the lesson content is determined by the number of learners attending it, which can range from 2 to 8 children depending on the specifics of a music instrument. For example, the number of children in percussion or piano classes may depend on the instruments available in the classroom. Meanwhile, much more learners can attend violin or guitar classes at a time because these instruments have a more subtle sound and do not create any inconveniences because of excessive noise in the classroom. The teachers were also asked what determines the success of learning in a group. The respondents emphasised that there are many success factors related to school environment, variety of music instruments, individual character features and musical abilities. However, teachers distinguished a set of teacher's personal qualities and abilities, which partially predetermine the lesson content and learners' achievements as well as contributes to establishment of good emotional atmosphere (Table 4). The most emphasised teachers' qualities included creativity, charisma, abilities of lesson planning and leading a group. The received responses of teachers highlighted 3 main categories generalising responses related to teacher's personality.

The researcher also made attempts to identify the differences between learning an instrument in a group and individual learning in terms of the set goals and their implementation. According to the respondents, individual lessons mainly focus on development of music performance skills and perfection of repertory performing. Meanwhile, the purpose of group lessons is slightly different. The process rather than the result is the main focus here: endeavours are undertaken to enable a learner to experience a joy of creation, to enjoy playing in an ensemble, to develop his or her creative abilities and to live through positive experiences of self-expression. These goals of group learning also presuppose significantly more varied learners' activities during the lesson. According to the teachers in the research, listening to music, learning the theory of music and playing an instrument are used in group lessons and these activities can be performed in a number of ways: students learn to improvise, to accompany, to compose and to illustrate. All this is particularly rarely used during individual lessons. 
The factors of successful instrument lesson related to the teacher's personality $(\mathrm{N}=6)$

\begin{tabular}{|c|c|c|}
\hline Category & Subcategory & Illustrating statement \\
\hline \multirow{3}{*}{$\begin{array}{l}\text { Teacher's } \\
\text { personal } \\
\text { qualities }\end{array}$} & creativity & $\begin{array}{l}\text { "Working with a group, a teacher requires a creative attitude not } \\
\text { only to a lesson but also to music education in general" }\left(5^{*}\right)\end{array}$ \\
\hline & sincerity & $\begin{array}{l}\text { "Very soon children start feeling the extent to which their } \\
\text { teacher is sincere with them" (3) }\end{array}$ \\
\hline & charisma & $\begin{array}{l}\text { "Every time you have to feel and act like on the stage, otherwise } \\
\text { you'll experience defeat" (5) }\end{array}$ \\
\hline \multirow[t]{3}{*}{$\begin{array}{l}\text { Teacher's } \\
\text { didactic } \\
\text { abilities }\end{array}$} & $\begin{array}{l}\text { striving for raising } \\
\text { general level of group } \\
\text { knowledge }\end{array}$ & $\begin{array}{l}\text { "Individual achievements of each learner as well as achievements } \\
\text { of the whole group are equally important to me" (1) }\end{array}$ \\
\hline & $\begin{array}{l}\text { differentiation of } \\
\text { presented learning } \\
\text { material }\end{array}$ & $\begin{array}{l}\text { "Though it is not easy but I try to present an assignment } \\
\text { according to the level of each child's perception and abilities" (2) }\end{array}$ \\
\hline & lesson planning abilities & $\begin{array}{l}\text { "It is impossible without improvisation but if you want to } \\
\text { improvise, you have to plan everything very well in the } \\
\text { beginning "(6) }\end{array}$ \\
\hline \multirow{3}{*}{$\begin{array}{l}\text { Teacher's } \\
\text { communicative } \\
\text { skills }\end{array}$} & $\begin{array}{l}\text { spontaneous response to } \\
\text { an unexpected situation }\end{array}$ & $\begin{array}{l}\text { "You have to react very fast because you may lose your } \\
\text { authority"(2) }\end{array}$ \\
\hline & flexibility of attitude & "I try to adapt and consider every learner’s opinion"(1) \\
\hline & ability to lead a group & $\begin{array}{l}\text { "If a teacher succeeds in bringing a group members together, } \\
\text { they will succeed in playing as well" (4) }\end{array}$ \\
\hline
\end{tabular}

*number of responses

The teachers were asked about what abilities and skills of learners are developed playing in a group and what advantages of this way of learning compared to individual teaching can be identified. The respondents provided a wide range of abilities, which were grouped into three categories. Table 5 shows that personal skills are best developed while learning an instrument in a group. Such social skills as learning to communicate and collaborate as well as development of musical skills are not left aside either.

Table 5

The influence of group learning on schoolchild's abilities $(\mathrm{N}=6)$

\begin{tabular}{|c|c|c|}
\hline Category & Subcategory & Illustrating statement \\
\hline \multirow{5}{*}{$\begin{array}{l}\text { Personal } \\
\text { skills }\end{array}$} & friendliness & $\begin{array}{l}\text { "Life in a group of people is always vibrant. It would be impossible to } \\
\text { adapt to other group members without friendliness" (4) }\end{array}$ \\
\hline & patience & "We train our patience while playing in a group" (3) \\
\hline & $\begin{array}{l}\text { concentration of } \\
\text { attention }\end{array}$ & $\begin{array}{l}\text { "Concentration of attention in such a lesson is of utmost significance" } \\
\text { (5) }\end{array}$ \\
\hline & $\begin{array}{l}\text { sense of } \\
\text { responsibility }\end{array}$ & $\begin{array}{l}\text { "I think that the sense of responsibility for the self and others is } \\
\text { developed strongest" (2) }\end{array}$ \\
\hline & motivation to learn & $\begin{array}{l}\text { "Learning in a group motivates you, especially, when you hear a friend, } \\
\text { who plays better" }(5)\end{array}$ \\
\hline \multirow{3}{*}{$\begin{array}{l}\text { Social } \\
\text { skills }\end{array}$} & communication & "It is more interesting to for schoolchildren in a group" (6) \\
\hline & collaboration & $\begin{array}{l}\text { "Collaboration occurs every minute during a lesson while playing in a } \\
\text { group" (6) }\end{array}$ \\
\hline & socialisation & $\begin{array}{l}\text { "Ability to adapt to other people is of utmost importance. School students } \\
\text { can learn this while playing in a group" (1) }\end{array}$ \\
\hline \multirow{3}{*}{$\begin{array}{l}\text { Musical } \\
\text { skills }\end{array}$} & $\begin{array}{l}\text { ability to play in } \\
\text { ensemble }\end{array}$ & "Playing in a group you learn to play as an ensemble" (2) \\
\hline & ability to interpret & "We learn to interpret. This is easier to learn this in a group than playing solo"(2) \\
\hline & $\begin{array}{l}\text { ability to hear } \\
\text { performing of others }\end{array}$ & $\begin{array}{l}\text { "The success of learning in a group is rooted in hearing others and I } \\
\text { always emphasise that to my learners" }(2)\end{array}$ \\
\hline
\end{tabular}

The negative expression of attitude towards learning an instrument in a group, which was identified during the research on the attitude of music school teachers towards music education innovations, encouraged an analysis of drawbacks of this way of teaching. Almost all the respondents pointed out that both teachers and learners feel certain inconveniences during such lessons. The teachers stated that lack of individual attention to every learner is the most difficult issue to deal with, which limits possibilities for addressing 
technical problems of playing. In group learning the moment of verbal encouragement or personal praise is delayed but such attention is important to every learner. Seeking to provide individual attention, teachers sometimes start hovering on the verge of a dynamic or chaotic lesson. The teachers also mentioned that learning in a group frequently results in a competitive environment. A healthy competitive atmosphere encourages attainment of the set goals. However, it can also evoke anxiety and lower self-confidence among more sensitive learners or strengthen their concern about falling behind the best peers. According to the research participants, the aforesaid problems can be eliminated combining learning in a group with individual lessons. The respondents are sure that group learning to play an instrument cannot replace individual lessons in any case but it can become one of alternatives of innovative education.

\section{Conclusions}

- Changing times have led to shifting needs of learners, which in its turn should also result in transformations of educational conditions, i.e. teaching goals, applied methods and forms. Education that imitates real-life situations, facilitates development of skills applicable in daily life and still complies with targeted education and development of personality has become of utmost importance lately. Music education innovations in the context of non-formal children education constitute an important step towards more sustainable education that considers the learner's preferences and contributes to creation of general welfare and culture in the country.

- The attitude of music school teachers in Lithuania towards music education innovations is of multi-dimensional nature. On the one hand, a favourable attitude towards adult and special education, a positive opinion about differentiated education and experimentation declare the desire of teachers to adapt to the epochal challenges. However, an unfavourable approach to learning an instrument in a group still reveals stagnation and a certain distrust in innovations, a doubt in their benefit and development, and probably an inability to organise innovative learning in practice. The teachers' attitude towards innovations is a specific projection of perspective music education that describes how education is implemented "today" and how this will be done "tomorrow".

- Learning an instrument in a group is a relatively new and only fragmentary applied educational practice. According to the opinion of teachers from music schools, who have experience in working with a group, learning an instrument in a group has a lot of advantages compared to individual learning. Playing in a group of peers, a school student learns to communicate and cooperate, more frequently lives through positive emotions and experiences the joy of music performing without much effort. However, such learning cannot equal individual teaching, which aims at perfect and complete interpretation of music composition. According to the opinion of participants in the research, possibility of applying both ways of teaching in parallel is likely to provide the variety to learning an instrument in a group and would make such education interesting and attractive to learners.

\section{Bibliography}

1. Antilla M., Lehtonen K. (2007). Problems in Finnish Music School. Problem in Music Pedagogy, 1, 81-93. Retrieved from https://du.lv/wp-content/uploads/2015/12/Volume_1_2007.pdf

2. Bastien J.W. (1999). How to Teach Piano Successfully (3rd ed.). San Diego, California: Neil A. Kjos Music Company.

3. Berezhnoi D.A. (2011). Problema individualno grupovogo muzykalnogo obucheniya detei [The Problem of Individual and Group Music Education of Children]. In E.B. Abdulin (Eds.), the international scientific-practical conference Pedagogy of Musical Education: Problems and Perspectives of Development, 3. Nizhnevartovsk: Nizhnevartovsk Humanitarian University, 212-216. (in Russian)

4. Björk C. (2016). In Search of Good Relationships to Music Understanding Aspiration and Challenge in Developing Music School Teacher Practices. Åbo: Åbo Akademi University Press. Retrieved from https://www.doria.fi/bitstream/handle/10024/122837/bjork_cecilia.pdf?sequence=2

5. Charmaz K. (2006). Constructing Grounded Theory. A Practical Guide through Qualitative Analysis. London: SAGE Publications. Retrived from http://www.sxf.uevora.pt/wpcontent/uploads/2013/03/Charmaz_2006.pdf

6. Daniel R. (2004). Innovations in Piano Teaching: a Small-Group Model for the Tertiary Level. Music Education Research, 6(1), 23-43. doi: 10.1080/1461380032000182911 
7. Fairchild J.A. (1996). Teacher's Guide to More Effective Group Piano Study. Piano Guild Notes, May/June, 4-6.

8. Gabnyte G. (2011). The Reasons and Premises of Changes Non-Formal Music Training System in Lithuania. Evaluation of Piano Teaching Programmes. In Time of Challenges and opurtunities: problems, Solutions, and Perspective: International Scientific-Practical Conference of Young Scientists and Students. Rezekne: SIA "ETRA", 260-267.

9. Gabnyte G. (2019). Features of Education in Lithuanian Music schools: Opinion of Students and Graduates. Music Science Today: the Permanent and the Changeable, 3(11). Daugavpils, Daugavpils University, 159-165.

10. Hallam S. (2010). The Power of Music: its Impact on the Intellectual, Social and Personal Development of Children and Young People. International Journal of Music Education, 28(3), 269-289. doi: $10.1177 / 0255761410370658$

11. Kaufmann K. (2015). Non-Formal Education in International Comparison: Patterns of Participation and Investment in Selected European Countries. International Journal for Research in Vocational Education and Training, 2(4), 239-267. doi: 10.13152/IJRVET.2.4.1

12. Kriščiūnaitė A., Strakšienè D. (2016). Tendencies of Future Music Teachers' Attitude Towards the Assessment of the Students' Progress and Achievements Under the Conditions of the Change of Educational Paradigms. Social Welfare: Interdisciplinary Approach, 1(6), 77-91. doi: $10.21277 /$ sw.v1i6.242

13. Laes T., Schmidt P. (2016). Activism within music education: Working towards inclusion and policy change in the Finnish music school context. British Journal of Music Education, 33(1), 5-23. doi: 10.1017/S0265051715000224

14. Lietuvos Respublikos švietimo istatymas [Law on Education of the Republic of Lithuania]. (2011). Retrieved from https://e-seimas.Irs.lt/portal/legalAct/lt/TAD/TAIS.395105 (in Lithuanian)

15. Luce D.W. (2001). Collaborative Learning in Music Education: A Review of the Literature. Update: Applications of Research in Music Education, 19(2), 20-25. doi: 10.1177/87551233010190020105

16. Luff P., Lebler D. (2013). Striking a Balance in Brass Pedagogy: Collaborative Learning Complementing One-to-One Tuition in the Conservatoire Curriculum. In H. Gaunt, H. Westerlund (Eds.), Collaborative Learning in Higher Music Education. Farnham: Ashgate, 173-178.

17. Maxwell J.A. (1996). Qualitative Research Design. An Interactive Approach. Applied Social Research Methods Series, Vol. 41. London: Sage.

18. Neformaliojo vaiku švietimo koncepcija [Conception of Non-formal Children Education]. (2012). Retrieved from https://www.smm.lt/uploads/documents/svietimas/neformalus\%20ugdymas/KONCE PCIJA\%202012\%2003\%2029\%20isak\%20Nr.\%20V-554.pdf (in Lithuanian)

19. Patton M.Q. (1990). Qualitative Evaluation and Research Methods ( $2^{\text {nd }}$ ed.). Newbury Park, London, New Delhi: Sage Publications.

20. Perulli E. (2009). Recognising non-formal and informal learning: An open challenge. Quality of Higher Education, 6, 94-115. Retrieved from https://www.vdu.lt/cris/handle/20.500.12259/728

21. Rogers A. (2005). Non-Formal Education-Flexible Schooling or Participatory Education? Springer US. doi: 10.1007/0-387-28693-4

22. Romi S., Schmida M. (2009). Non-Formal Education: a Major Educational Force in the Postmodern Era. Cambridge Journal of Education, 39(2), 257-273. doi: 10.1080/03057640902904472

23. Rowe Ch. (1999). Class Piano Lessons After 30 Good Years. Clavier, 38, 6-7. Retrieved from https://openmusiclibrary.org/article/810427/

24. Swanwick P., Swanwick K. (1994). Musical Knowledge: Intuition, analysis and music education. London, New York: Routledge, Falmer. doi: 10.4324/9780203424575

25. Šiaučiukėnienė L., Stankevičienė N., Čiužas R. (2011). Didaktikos teorija ir praktika [Theory and Practice of Didactics]. Kaunas: KTU leidykla Technologija. (in Lithuanian)

26. Thoidis I., Pnevmatikos D. (2014). Non-Formal Education in Free Time: Leisure-Or Work-Orientated Activity? International Journal of Lifelong Education, 33(5), 657-673. doi: 10.1080/02601370.2014.918197

27. Vaiku ir jaunimo socializacijos programa [Programme for Children and Youth Socialisation]. (2010). Retrieved from https://e-seimas.lrs.lt/portal/legalAct/lt/TAD/TAIS.383712?jfwid=-je7i1syyn (in Lithuanian)

28. Valstybines švietimo 2013-2022 mety strategijos igyvendinimas [Programme of Implementation of Provision of the State Education Strategy for 2013-2022]. (2015). Vilnius: Švietimo aprūpinimo centras Retrieved from https://www.smm.lt/uploads/lawacts/docs/687_990ea392c0adc4c25c657236b66583c4.pdf (in Lithuanian) 